Article

\title{
How Do Technological Skills Improve Reverse Logistics? The Moderating Role of Top Management Support in Information Technology Use and Innovativeness
}

\author{
Encarnación García-Sánchez ${ }^{1, * \mathbb{C}}$, Jaime Guerrero-Villegas ${ }^{2} \mathbb{C}$ and Javier Aguilera-Caracuel ${ }^{3}$ \\ 1 Department of Management, Faculty of Education, Economics and Technology, University of Granada, \\ 51001 Ceuta, Spain \\ 2 Department of Management and Marketing, Universidad Pablo de Olavide, 41013 Seville, Spain; \\ jguevil@upo.es \\ 3 Department of Management, Faculty of Economic and Business Sciences, University of Granada, \\ 18071 Granada, Spain; javieraguilera@ugr.es \\ * Correspondence: encags@ugr.es
}

Received: 26 November 2018; Accepted: 19 December 2018; Published: 22 December 2018

check for updates

\begin{abstract}
The purpose of this paper is to explore the influence of human resource management on reverse logistics (RL) in the context of high-tech firms. Using the resource-based view of the firm, we analyzedthe effect of employees' technological skills on RL. The study also investigated whether top management support (TMS) for information technology (IT) and innovativeness moderate this relationship. We collected data from European high-tech firms from May to September 2010, obtaining 160 responses representing a $17.7 \%$ response rate. Multivariate regressions were used to assess all of the relations established. The results indicated that technological skills have direct and positive effects on RL in high tech-firms. The authors also report that both TMS for IT and innovativeness act as positive moderators in the relationship between technological skills and RL. This study suggests the importance of considering two important organizational variables that enhance the effect of technological skills on RL in high-tech firms. First, using TMS for IT not only provides tangible resources but also strongly supports employees' technological development in RL. Second, a high level of firm innovativeness leads high-tech firms to create the right conditions to take advantage of their technological skills to improve their RL. Moreover, theresults indicate the contingent role of innovativeness and TMS for IT use in the relationship between technological skills and RL.
\end{abstract}

Keywords: reverse logistics; technological skills; top management support; innovativeness

\section{Introduction}

The current global scenario, characterized by competitive and dynamic markets, has led firms to focus their efforts on developing more sustainable strategies. In this context, supply chain management (SCM) has become pivotal for sustainable development of firms, since it involves major business and industrial activities such as raw materials extraction, procurement, manufacturing, packaging and transportation, all of which can pose negative environmental and social impacts if not managed appropriately [1].

Reverse logistics (RL) is a key element of SCM. RL can be defined as "the process of planning, implementing, and controlling the efficient, cost effective flow of raw materials, in-process inventory, finished goods, and related information from the point of consumption to the point of origin for the purpose of creating or recapturing value, or proper disposal" [2] (pp. 271). A higher volume of returns 
(e.g., product warranties, end-of-use, end-of-life) and recalls makes RL essential to firms' success. Within the Resource-Based View [3,4], RL can be understood as a strategic resource that can help the firm obtain a competitive advantage through the efficient recovery of the value of products [5]. From this perspective, human resources are considered as one of the crucial intangible resources for the development and maintenance of efficient RL activities. Thus, effective RL can positively affect the company's economic, social and environmental sustainability by recapturing value remaining in the returned product [6].

Studies have focused on describing and analyzing RL system planning, reverse channel activities and problems that firms encounter in the RL process. Another line of research examines the ways different elements in the RL process interact and share information [7,8]; development of and relationships among members of the supply chain $[9,10]$; collaborative production models for planning returns [11]; governance policies [12,13]; warehousing and environmental sustainability (green RL) [14], among others. However, how human resources can contribute to the development of RL has received little study.

Some authors indicatethe key role played by internal and external factors in facilitating or inhibiting implementation of RL $[15,16]$. The majority of these studies analyze economic issues, environmental issues, market issues andproduct quality, among other issues. Additionally, the literature has shown that information technology (IT) resources are required for effective decision making in RL [17]. All of these activities require advanced IT systems. While organizations have developed sophisticated forward-logistics technology, IT that supports RL lags significantly, creating serious challenges [6,18]. As both control throughout the supply chain and transparency depend on IT [19], not developing appropriate IT systems hinders the efficiency of RL processes [20].

Despite all of these advances, the literature has paid little attention to analyzing the role played by human resource management in firms' RL activities. Specifically, little research has explored the influence of workers' technological skills, which can be key intangible resources [21,22]. Yet, these skills are highlyrelevant to RL processes within organizations in very dynamic, unstable high-tech sectors. First, RL requires processes that incorporate a continuous flow of information among the agents involved in the supply chain to coordinate and execute the return process efficiently [23-25]. Achieving this goal takes effort and dedication from the firm's workers in developing technological skills [26,27] such that workers can access information simultaneously [28] and achieve greater collaborative support among the agents involved. Human capital can affect RL, since human resources are the company's most valuable asset in providingcompetitive advantage [22,29].

Second, when analyzing the impact of workers' technological skills on RL processes, one must consider a series of organizational variables that help to strengthen this relationship. Specifically, we analyzed the Top Management Support (TMS) for IT use and innovativeness. On the one hand, diverse studies have indicated that TMS is a critical component to the success of any logistics process $[26,30]$. The costs and risk involved in RL processes in the high-tech sector currently require top managers who areoriented to these processes and support them, focusing intensely on the use and implementation of new technologies to ensure good acceptance and implementation. This support is necessary to committing sufficient funding through a suitable level of technological and human resources-hiring, training and developing employeesand coordinating the different players involved in the RL processes [31]. An effective increase of employees' technological skills and professional development depends on TMS, as top managers allocate resources and develop the plansthat guide their companies in pursuit of their strategic goals [32]. Organizations can benefit from this knowledge in RL processes if managers truly bid for technological training and improvement and train employees to obtain complex, tacit technological skills that are difficult to copy.

Innovativeness, on the other hand, makes firms adopt new technologies earlier [31] and implies seeking creative or novel solutions to problems [33]. Companies must innovate to succeed in RL, which differs from forward logistics and outbound flows, requiring dedication of further resources and special handling [34]. Organizational creativity and flexibility are two essential elements of 
innovativeness that help organizations to meet this need, as they enhanceemployees' technological skills, improving RL performance [31,35].

Bearing the foregoing in mind, this study aimedto analyze the following research questions in high-tech firms: To what extent do employees' technological skills affect the company's RL activities? What role do organizational variables such as TMS and innovativeness play in the relationship between employees' technological skills and the RL? In answering these questions, this study contributes to the literature in several ways. First, it highlights the role played by human resource management in the development of RL activities. Specifically, it provides support to demonstrate that firms whose employees possess technological skills enhance RL. Second, the paper advances the literature on the manager's role, by going beyond previous work to study the importance of TMS in RL and by suggesting that specific top managers' support for IT is needed to develop RL. Third, this paper enriches the RL literature by considering the contingent role of innovativeness in the relationship between technological skills and RL.

The rest of the paper is structured as follows. The next sectionestablishesthe theoretical framework and develops the hypotheses. The third section explains the methodology, including description of the sample and definition of the variables. Results are presented in the fourth section. The fifth and final section provides discussion, conclusions andlimitations of the study and recommendations for further research.

\section{Hypotheses}

\subsection{Technological Skills and RL}

The last two decades have produced a drastic change in the functioning of firms that perform SCM, especially in RL. RL activities may affect firms' sustainability. For example, effective RL strategies can decelerate or prevent environmental degradation and require employees' new skills, and product and process technology capacities [36]. Thus, we can draw on the resource-based view [21,22] to argue that skills possessed by employees are key to developing efficient RL activities [31]. Specifically, technological skills are defined as "the know-how needed to build IT applications using available technology and to operate them to make products or provide services" [37] (p. 498). Technological skills include knowledge of programming languages, understanding of communication protocols and products and experience with operating systems. Thus, there are various reasons why firms that perform RL processes need their workers to develop technological skills.

First, the complexity and speed of logistics operations make information management a priority for firms globally. This finding is especially true for high-tech firms, which are often characterized by uncertainty and the need for rapid synchronization of processes and processing of information and actions [24]. In some industries, for example, prediction of the type and number of returns can be based on historical information; however, these predictions are more difficult to establish in the technology sector, where information varies and changes over time [24]. In addition to predicting what products will be returned when, companies must respond quickly to customer requests, processing and managing product flows quickly and accurately. Given the complexity of interactions among the various parties, companies should optimize coordination among them by prioritizing effective access to and exchange of information [24].

Second, skilled employees can exploit the power of technology to organize information and make it available to multiple users whenever needed. Thus, employees must know how to maximize use of the tools available (e.g., databases, varied media, simulation software, portals/forums and networks for communication and exchange of information and knowledge $[28,38])$. Furthermore, possession of technological skills by an organization's workers is always an important element for the firm, as it is a means of strengthening technological knowledge and exploring new results [39]. These skills are even more noteworthy in high-tech firms, which perform RL processes that involve continuous innovation and incorporation of new technology in the entire process of asset recovery. For example, technological 
skills are necessary in the application of software for storing and gathering data that enable one to know at what moment packages are returned by the supplier, whether the products are defective or unused, etc. [40].

Third, technological skills are needed to support collaborative communication with supply chain members, that is, in the collaborative relationships among the agents of the supply chain, through significant and opportune exchange of information [41]. RL succeeds when the different members of the chain know and trust each other [39]. Meetings and frequent information exchange foster and improve relationships to ground effective collaboration on RL operations [42]. Such collaboration also depends on a shared vision that subordinates individual and short-term interests to the long-term commitment $[43,44]$. Using technologies and developing technological skills that encourage communication and mutual trust can be considered precursors to a stable, committed relationship among supply chain agents [45]. Precisely due to the variability of RL processes, commercial members should work together to ensure the punctuality and efficiency of the activity.

Following the resource-based view of firm rationality, human resources are key to developing RL activities. They are even more crucial in the high-tech sector, which is characterized by constant research and innovation, and thus requires that personnel be not only highly qualified but also constantly up-to-date. Not only are continuous training and renewal essential to being technologically competitive [46], employees must be able to change, adapt and coordinate in new processes as the organization evolves. Such flexibility often necessitates acquiring new technological knowledge. Thus, we conclude that workers with technological skills will be able to improve their RL processes by developing and disseminating technological knowledge among all agents in the supply chain.

Hypothesis 1. Technological skills are positively related to RL in high-technology firms.

\subsection{The Moderating Role of TMS for IT Use in the Relationship between Technological Skills and RL}

Once the relation between technological skills and RL has been analyzed, we must identify other factors that can affect the firm's RL activities [47]. TMS for IT is one factor that influences firms' tendency to develop RL processes [31].

Various studies have noted that logistics processes depend on TMS [24,30,48]. Firms should take into account human intangible resources to develop their RL strategies. Thus, the promotion and support of employee technological skills becomes crucial [21,22,49]. From this point of view, top managers usually plan carefully to allocate sufficient resources (monetary and human), training and implementation of RL. Only thenwill their firms be prepared to succeed despite the risk and expense involved [31].

First, the TMS is shown in investment in IT and in the acquisition of tools and applications, among other items, that permit development of RL processes and thus create a competitive advantage through the development of resources that are sustainable and inimitable over time [27,50]. IT can enhance the firm's competitive ability to create and capture value through positioning advantages in its industry and/or coordination advantages in its value chain [51,52]. According to [26], one strategic concern for top managers is the deployment of IT in the supply chain. TMS "reflects, in many ways, the importance that top management executives place on technology" [53] (pp. 246). The CEO and the Chief Information Officer (CIO) typically determine firms' IT strategy and investment [54]. Unless CEOs understand the magnitude of the investment required, they are unlikely to approve major projectsor the resources required for successful implementation. In the absence of such understanding, projects of great importance to the firm's position in its sector may not receive sufficient funding $[48,54]$.

Second, TMS can be reflected in good personnel selection and training policies. On the one hand, selection policies help the company to strengthen its personnel's technological skills by incorporating people who already possess these skills when they join the company [37]. For example, manufacturing firm managers' decision to invest in technology specific to RL could lead to including personnel with specific technological abilities in automated materials handling, equipment monitoring, computerized 
entry of returns and exchange of electronic data [8] that permit rapid response to customers. Such technological support would help to recover value that would otherwise be lost, improving the relationship among supply chain agents through customer service and satisfaction [24].

On the other hand, TMS can influence the increase and perfecting of continuous and intensive training programs on RL processes [29]. Managers' concern for the professional development of their employees largely determines the resources dedicated to training as a significant element of the firm's strategic plan [32].

In sum, we propose that the positive effect of technological skills on RL is more evident for firms with a high level of TMS for IT. In other words, TMS for IT has a positive effect on the relationship between technological skills and RL in high-technology firms, as formulated in the following hypothesis:

Hypothesis 2. TMS for IT use is likely to strengthen the positive relationship between technological skills and RL in high-technologyfirms.

\subsection{The Moderating Role of Organizational Innovativeness in the Relationship between Technological Skills and $R L$}

In today's volatile, competitive markets, competition pushes organizations to change rapidly and innovate [55]. Various studies stress the specific importance of innovation in RL programs [30].

We can define innovativeness as the organization's adoption of new technologies earlier than peers [56] or the discovery oforiginal solutions to problems [33]. RL depends more intensely on innovation than other processes because reverse flows are so different from forward, requiring different treatment and greater investment in resources [34]. Organizations that dedicate attention to RL processes and remain current with changes in technology will be better able to adopt new technologies to excel in RL and, in turn, in market performance [31].

Several studies highlight that certain organizational factors enhance innovativeness. According to Fundación COTEC for innovation, an environment inclined to innovation is one that bids for and values innovation possesses the processes and tools needed and allocates resources to managing them. One of the most striking issues in establishing such an environment is creativity. Following the theoretical framework, firms that promote employees' creative capacities, tolerate risks and support personal development improve product innovation outputs [35]. In such situations, firms are more likely to develop and renew their products and processes, abandoning obsolete ones and encouraging the firm's growth and profitability in the long term [57]. Failure to adopt emerging technologies and remain current will, in contrast, prevent the company from competing with more innovative competitors.

According to Frohman (1998) [58], organizations that sustain a climate of innovation: (1) foster ongoing horizontal communication, (2) reward employees for innovative ideas, (3) promote employee feedback, (4) establish methods to measure learning and (5) celebrate rather than punish mistakes, which are viewed as learning opportunities.

Creative, flexible development over time throughout the organization nurtures RL process innovation, giving rise to strategic initiatives [38]. Organizations with these characteristics can better (1) predict customer demand, preference, and dissatisfaction with products and services; (2) establish new return policies, collection points or customer services that make the process more efficient; and (3) use information from the entire supply chain network to develop products and services that better satisfy customers' needs, optimizing asset recovery [59].

In sum, we propose that organizational innovativeness can strengthen the positive relationship between technological skills and RL in high-tech firms. Specifically, a high level of innovativeness can facilitate access to information, the search for creativity and provision of unusual solutions to problems, and the ability of employees to develop their technological skills, positively impacting RL. 
Hypothesis 3. Organizational innovativeness is likely to strengthen the positive relationship between technological skills and RL in high-technology firms.

Figure 1 presents the proposed theoretical model.

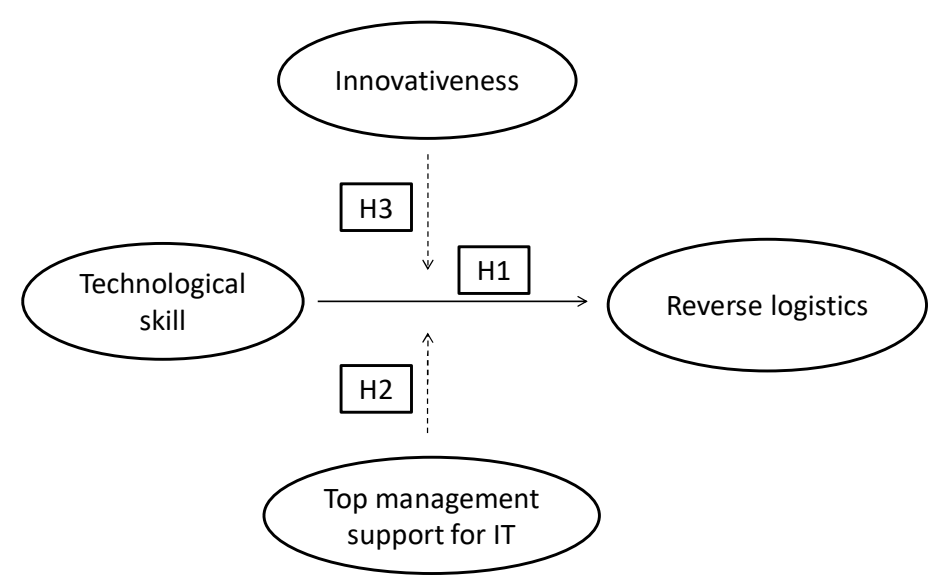

Figure 1. Research model.

\section{Methodology}

\subsection{Sample}

The study population was composed of high-technology firms within the territory of the European Union due to the importance of RL in the technology sector. The sample of 900 firms was drawn from Amadeus (2009) [60], acomplement to Thomson Reuters' Datastream, which compiles thorough information on the financial and business assetsof some19 million companies in 43 countries in Europe. We prepared a structured questionnaire to study how organizations tackle RL, drawing on our knowledge of the literature, expert scholarly and managerial contacts, and additional interviews with other scholars and managers. The list of these organizations' CEOs was obtained in partthrough funding from the Regional Ministry of Economy, Innovation and Science of Andalusia's Regional Government and the Spanish Ministry of Science and Research.

CEOs, our main respondents, provided significant input for constructing and refining the study variables. CEOs were the main respondents because of their responsibility to evaluate and monitor in-depth information throughout the organizationand to establish norms for employee behavior [61]. Additionally, CEOs outline the organization's goalsand plan and oversee implementation of its initiatives and progress toward them [62].

Through stratified random sampling by country, we divided the study population (10 EU countries: Austria, Belgium, Denmark, France, Germany, Italy, Poland, Spain, The Netherlands, the United Kingdom) into strata, with random sampling within strata through systematic sampling. We then selected 16 companies from each of the 10 countries. The CEOs were assured that their responses would be confidential and reported only in aggregate form. CEOs were offered the opportunity to receive the study results, with a comparative analysis of their firm's variables. This procedure yielded a $17.7 \%$ response rate (Table 1 ). 
Table 1. Technical details of the research.

\begin{tabular}{cc}
\hline Sectors & $\begin{array}{r}\text { High-tech manufacturing firms (pharmaceutical industry, } \\
\text { hardware and other computer science equipment, automotive } \\
\text { industry, space and aeronautics products). }\end{array}$ \\
\hline Geographical location & $\begin{array}{r}\text { Europe (Austria, Belgium, Denmark, France, Germany, Italy, } \\
\text { Poland, Spain, The Netherlands, United Kingdom) }\end{array}$ \\
\hline Methodology & Structured questionnaire \\
\hline Universe of population & 5441 firms \\
\hline Sample (response) size & 160 firms (17.7\%) \\
\hline Sample error & $7.7 \%$ \\
\hline Confidence level & $95 \%, p-q=0.50 ; Z=1.96$ \\
\hline Period of data collection & From May 2010 to September 2010 \\
\hline
\end{tabular}

The EU context was suitable for this study because of the significant role of its RL and technologies in promoting green supply management practices internationally [63]. We compared responding and non-responding businesses' to reduce likelihood of non-response bias. The results for return on assets (ROA), return on equity (ROE) and return on sales (ROS) showed no significant difference between respondents and non-respondents [64]. The use of a single survey instrument required testing for common method bias, in this case with Harman's one-factor test (see [65]). From the principal components analysis of the questionnaire, eight factors with Eigen-values over 1.0 explained $64 \%$ of the variance. Thus, method variance did not seem to be a concern. We identified several factors, rather than merelyone, and no single factor explained the majority of the variance [66].

\subsection{Variables}

Technological skills. Scales from Ray et al. (2005) [67] and Byrd and Davidson (2003) [53] were used to measure technological skills on a four-item 7-point Likert scale (1 "completely disagree", 7 "completely agree") (Appendix A). Confirmatory factor analysis (CFA) $\left(\chi^{2}{ }_{2}=1.26, \mathrm{NFI}=0.99\right.$, $\mathrm{NNFI}=0.99, \mathrm{GFI}=0.99, \mathrm{CFI}=0.99)$ demonstrated the scales' one-dimensionality, high validity and reliability $(\alpha=0.849)$.

Organizational innovativeness. We measured organizational innovativeness using four-item, 7-point Likert-type scales (1 "completely disagree", 7 "completely agree") from Zahra (1993) [68] [Appendix A]. CFA was used to validate this scale $\left(\chi^{2}{ }_{2}=4.30, \mathrm{NFI}=0.98, \mathrm{NNFI}=0.97, \mathrm{GFI}=0.99\right.$, $\mathrm{CFI}=0.99)$. The results showed its one-dimensionality and satisfactory validity and reliability $(\alpha=0.792)$.

Top management support. Byrd and Davidson (2003) [53] and Ray et al. (2005) [67] provided the four items to measure TMS [Appendix A]. CFA $\left(\chi^{2}{ }_{2}=1.19, \mathrm{NFI}=0.99, \mathrm{NNFI}=0.99, \mathrm{GFI}=0.99\right.$, $\mathrm{CFI}=0.99)$ was used to validate the scales and confirm their one-dimensionality, high validity and reliability $(\alpha=0.80)$.

Reverse logistics. RL was measured using six items from Mihi-Ramirez (2012) [63] and an adaptation from [2] [Appendix A]. CFA $\left(\chi^{2}{ }_{2}=1.21, \mathrm{NFI}=0.99, \mathrm{NNFI}=0.97, \mathrm{GFI}=0.98, \mathrm{CFI}=0.99\right)$ was used to validate the scales and confirm their one-dimensionality, high validity and reliability $(\alpha=0.812)$.

Organizational performance. A six-item, 7-point Likert-type scale (1 “Much worse than my competitors" to 7 "Much better than my competitors") by Murray and Kotabe (1999) [69] was used to assess organizational performance relative to direct competitors. Scales have been used extensively in recent research to evaluate performance relative to main competitors [70,71]. In many studies, the managers' subjective perceptions have been the basis for determining the success of the firms' outcomes. In others, researchers have used objective data, such as ROA. Research has confirmed the high correlation and concurrent validity of objective and subjective data on performance. Both are 
considered valid to calculate organizational performance [72,73]. Although the interview questions were also formulated to obtain both subjective and objective information, CEOs preferred to give general opinions rather than numerical data (Appendix A). We confirmed the correlation between subjective and objective data and found that they were high and significant. The scales were validated using CFA $\left(\chi^{2}{ }_{2}=24.60, \mathrm{NFI}=0.94, \mathrm{NNFI}=0.94, \mathrm{GFI}=0.98, \mathrm{CFI}=0.96\right)$ and were demonstrated to be one-dimensional with high reliability $(\alpha=0.816)$.

Table 2 summarizes variables and their operationalization.

Table 2. Variables and operationalization.

\begin{tabular}{|c|c|c|}
\hline Variable & Operationalization & $\begin{array}{l}\text { Confirmatory Factor Analysis } \\
\text { (CFA)/Reliability }\end{array}$ \\
\hline Technological skills & $\begin{array}{l}\text { Technical information technology (IT) skills refer to } \\
\text { general, explicit skills (e.g., programming) } \\
\text { possessed by the firm's IT staff that are needed to } \\
\text { develop IT applications; and encompass both } \\
\text { firm-specific techniques and scientific } \\
\text { understanding (Ray et al., 2005) [67]. }\end{array}$ & $\begin{array}{c}\text { Confirmatory factor analysis: } \\
\chi_{2}^{2}=1.26, \text { NFI }=0.99 \\
\text { NNFI }=0.99, \text { GFI }=0.99 \\
\text { CFI }=0.99 \\
\text { Reliability: } \alpha=0.849\end{array}$ \\
\hline $\begin{array}{l}\text { Organizational } \\
\text { innovativeness }\end{array}$ & $\begin{array}{l}\text { The ability of the organization to adapt or execute } \\
\text { new ideas, processes or products satisfactorily, } \\
\text { emphasizing creating new business through } \\
\text { market developments or by undertaking product, } \\
\text { process, technological and administrative } \\
\text { innovations (Zahra, 1993) [68]. }\end{array}$ & $\begin{array}{c}\text { Confirmatory factor analysis: } \\
\chi^{2}{ }_{2}=4.30, \mathrm{NFI}=0.98 \\
\mathrm{NNFI}=0.97, \mathrm{GFI}=0.99 \\
\text { CFI }=0.99 \\
\text { Reliability: } \alpha=0.792\end{array}$ \\
\hline $\begin{array}{l}\text { Top management } \\
\text { support for IT }\end{array}$ & $\begin{array}{l}\text { Top management support (TMS) for IT reflects the } \\
\text { importance that the top management executives } \\
\text { place on IT, the level of funding for IT and the } \\
\text { facilitation of technology transfer throughout the } \\
\text { firm (Byrd and Davidson, 2003) [53]. }\end{array}$ & $\begin{array}{c}\text { Confirmatory factor analysis: } \\
\chi^{2}{ }_{2}=1.19, \mathrm{NFI}=0.99 \\
\mathrm{NNFI}=0.99, \mathrm{GFI}=0.99 \\
\text { CFI }=0.99 \\
\text { Reliability: } \alpha=0.80\end{array}$ \\
\hline Reverse logistics & $\begin{array}{l}\text { Implementation and control of the flow of raw } \\
\text { material, inventory in process, finished products } \\
\text { and information from point of consumption to } \\
\text { point of origin, to be done as efficiently and } \\
\text { economically as possible in order to recover its } \\
\text { value (Rogers and Tibben-Lembke, 1999) [2]. }\end{array}$ & $\begin{array}{c}\text { Confirmatory factor analysis: } \\
\chi^{2}{ }_{2}=1.21, \mathrm{NFI}=0.99 \\
\mathrm{NNFI}=0.97, \mathrm{GFI}=0.98 \\
\text { CFI }=0.99 \\
\text { Reliability: } \alpha=0.812\end{array}$ \\
\hline $\begin{array}{l}\text { Organizational } \\
\text { Performance }\end{array}$ & $\begin{array}{l}\text { Market performance consisted of two composite } \\
\text { measures of strategic market performance and } \\
\text { financial market performance, using managers' } \\
\text { subjective perceptions to measure beneficial } \\
\text { outcomes for firms and others objective data, such } \\
\text { as return on assets (ROA) (Homburg et al., 1999; } \\
\text { Murray and Kotabe, 1999; Venkatraman and } \\
\text { Ramanujam, 1986) [69,72,73]. }\end{array}$ & $\begin{array}{c}\text { Confirmatory factor analysis: } \\
\chi^{2}{ }_{2}=24.60, \mathrm{NFI}=0.94 \\
\mathrm{NNFI}=0.94, \mathrm{GFI}=0.98 \\
\mathrm{CFI}=0.96 \\
\text { Reliability: } \alpha=0.816\end{array}$ \\
\hline
\end{tabular}

\section{Results}

A multiple moderated regression analysis [74] was used to test the hypotheses, with the moderating effect servingas multiplicative variable. Then, we assessed the probability of common method variance, whether the data followed the distribution expected fromour analytic tools, and the independent variables' degree of multicollinearity. We developed the multiplicative terms by fixing both independent and moderating variables on their means to prevent multicollinearity [75]. According to the results of the Kolmogorov-Smirnov test, the variable distributions generally conformed to the normality assumption of regression analysis. The condition indices and variance inflation factors (VIF) enabled us to discount the possibility that multicollinearity skews the results, as the VIF values were below the maximum of five recommended in the literature [76]. Additionally, we tested for heteroscedasticity using the Breusch-Pagan test. The result indicated that there were no problems of heteroscedasticity in our model. The descriptive statistics and correlations are shown in Table 3. 
Table 3. Descriptive statistics and correlations.

\begin{tabular}{|c|c|c|c|c|c|c|c|c|c|c|}
\hline & Mean & $\begin{array}{l}\text { Standard } \\
\text { Deviation }\end{array}$ & $\begin{array}{l}\text { Reverse } \\
\text { Logistics }\end{array}$ & Firm Size & Sector 1 & Sector 2 & Sector 3 & Performance & $\begin{array}{c}\text { Technological } \\
\text { Skills }\end{array}$ & $\begin{array}{c}\text { Top } \\
\text { Management } \\
\text { Support for IT }\end{array}$ \\
\hline Reverse logistics & 0.00 & 1.00 & 1.00 & & & & & & & \\
\hline Firm size & 3.81 & 1.76 & $0.27^{* * *}$ & 1.00 & & & & & & \\
\hline Sector 1 & 0.26 & 0.57 & $0.19^{* *}$ & 0.01 & 1.00 & & & & & \\
\hline Sector 2 & 0.23 & 0.55 & $-0.10^{\dagger}$ & $-0.25^{* *}$ & $0.32^{* * *}$ & 1.00 & & & & \\
\hline Sector 3 & 0.32 & 0.59 & -0.07 & 0.04 & 0.22 & 0.26 & 1.00 & & & \\
\hline Performance & 0.00 & 1.00 & $0.18^{* *}$ & $0.22 * *$ & 0.03 & 0.09 & 0.06 & 1.00 & & \\
\hline Technological skills & 0.00 & 1.00 & $0.27^{* * *}$ & $0.11^{\dagger}$ & 0.02 & $0.14^{*}$ & 0.11 * & $0.28^{* * *}$ & 1.00 & \\
\hline $\begin{array}{l}\text { Top management } \\
\text { support for IT }\end{array}$ & 0.00 & 1.00 & $0.35^{* * *}$ & $0.18^{* *}$ & 0.09 & 0.08 & 0.09 & $0.41^{* * *}$ & $0.65^{* * *}$ & 1.00 \\
\hline Innovativeness & 0.00 & 1.00 & $0.35^{* * *}$ & $0.18^{* *}$ & 0.17 * & $0.11^{\dagger}$ & $0.15^{*}$ & $0.32 * * *$ & $0.42^{* * *}$ & $0.57^{* * *}$ \\
\hline
\end{tabular}


Table 4 shows the results of the regression analyses testing the hypotheses.

Table 4. The results of the hierarchical moderating regression analysis.

\begin{tabular}{ccccc}
\hline & Model 1 & Model 2 & Model 3 & Model 4 \\
\hline Constant & $-0.47^{*}(0.19)$ & $-0.34^{* *}(0.2)$ & $-0.32^{+}(0.18)$ & $-0.36^{*}(0.18)$ \\
Firm size & $0.12^{* *}(0.04)$ & $0.09^{*}(0.04)$ & $0.18^{*}(0.09)$ & $0.09^{*}(0.04)$ \\
Sector 1 & $0.43^{* *}(0.14)$ & $0.39^{*}(0.14)$ & $0.33(0.13)$ & $0.36^{* *}(0.13)$ \\
Sector 2 & $-0.19(0.15)$ & $-0.28^{*}(0.06)$ & $-0.34^{*}(0.14)$ & $-0.26(0.15)$ \\
Sector 3 & $-0.19(0.13)$ & $-0.17(0.13)$ & $-0.21(0.12)$ & $-0.22(0.13)$ \\
Performance & $-0.19^{*}(0.13)$ & $0.03(0.07)$ & $0.07(0.07)$ & $0.04(0.08)$ \\
Technological skills & & $0.17^{* *}(0.08)$ & $0.29^{* * *}(0.08)$ & $0.13^{*}(0.09)$ \\
Top management support for IT & & $0.32^{* *}(0.11)$ & $0.26^{* *}(0.08)$ & $0.32^{* *}(0.11)$ \\
Innovativeness & & $0.22^{* *}(0.08)$ & & $0.11^{* *}(0.05)$ \\
TMS X technological skills & & & $0.21^{* * *}(0.05)$ & 0.26 \\
Innovativeness X technological skills & & & 0.31 & 0.25 \\
$R^{2}$ & 0.15 & 0.25 & 0.28 & $4.93^{* *}$ \\
$R^{2}$ adjusted & 0.12 & 0.21 & $15.92^{* * *}$ & \\
F change & $5.34^{* *}$ & $9.28^{* *}$ & & \\
\hline
\end{tabular}

Notes: Dependent variable: Reverse logistics. $R^{2}$, Reliability; Standardized Structural Coefficients; ${ }^{\dagger} p<0.10$, ${ }^{*} p<0.05,{ }^{* *} p<0.01, * * * p<0.001$.

In Model 1, the control variables were entered: firm size, type of industry and performance. In Model 2, we added the independent variables: technological skills, TMS for IT use and innovativeness.

Model 3 included the moderating effect of TMS on IT use in the relationship between technological skills and RL. Finally, Model 4 considered the moderating effect of innovativeness on the relationship between technological skills and RL. Our models showed good fit, with an adjusted $R^{2}$ value greater than 0.20 for all four. We now highlight our main results.

First, the results showed that technological skills werepositively and significantly related to RL, supporting H1. Second, since the greater the TMS for IT use, the stronger the relationship between technological skills and RL, TMS for IT use strengthened the positive effect of technological skills on the development of green RL. Figure 2 illustrates this relationship. Consequently, Hypothesis 2 is supported.

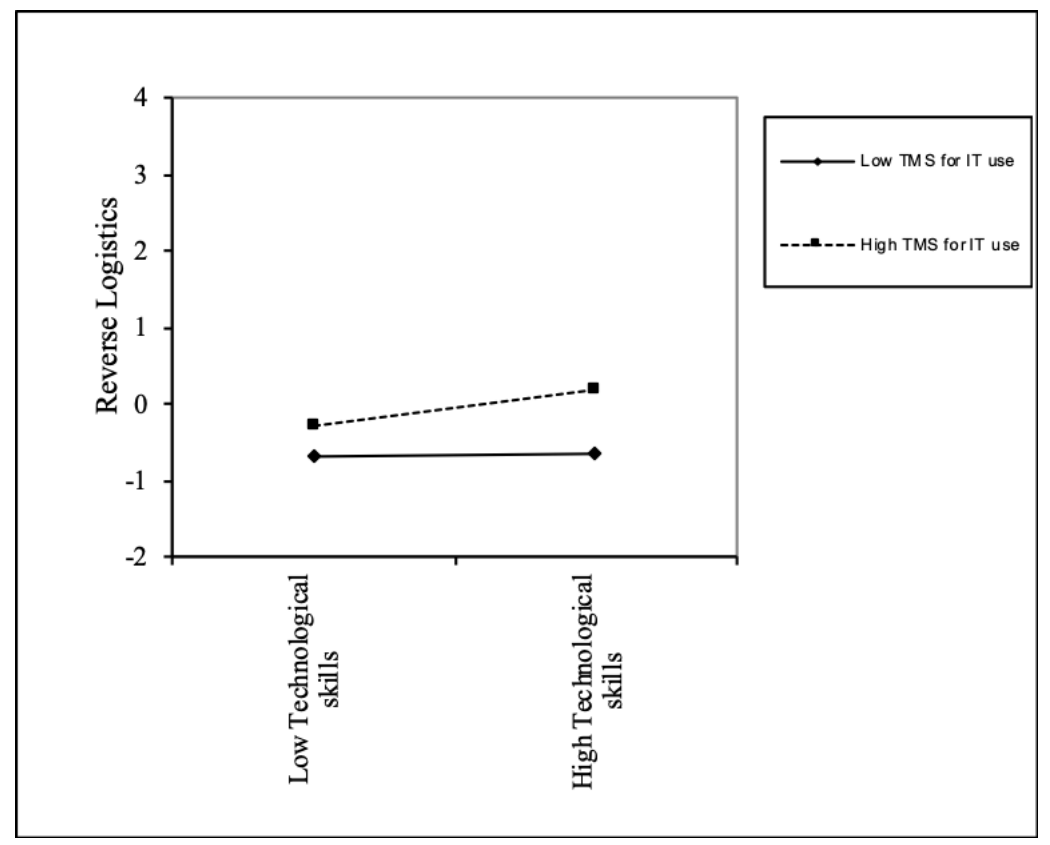

Figure 2. Moderating effect of TMS for IT use on the relationship between reverse logistics (RL) and technological skills. 
Finally, since the greater the level of firm innovativeness, the stronger the relationship between technological skills and RL, innovativeness strengthened the positive effect of technological skills on the implementation of RL processes. Figure 3 illustrates our findings. Hence, Hypothesis 3 is also supported by our data.

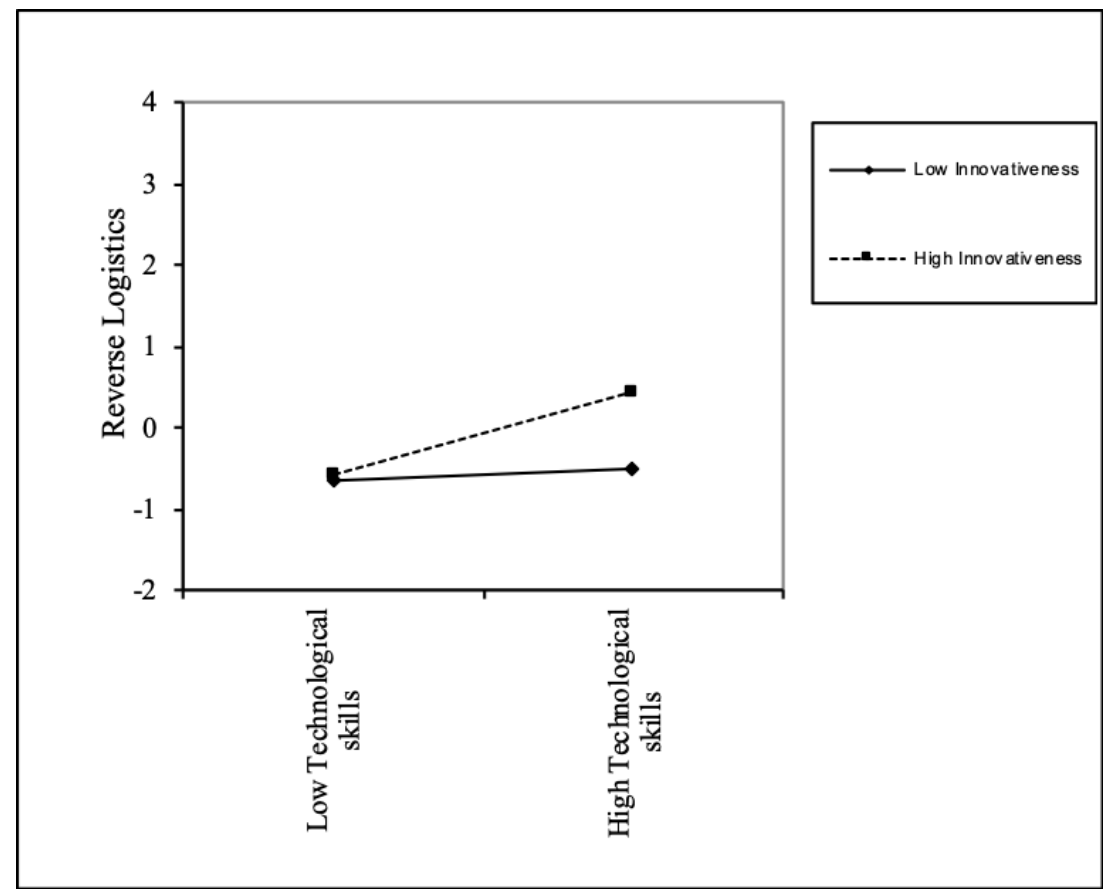

Figure 3. Moderating effect of innovativeness on the relationship between RL and technological skills.

\section{Discussion and Conclusions}

Due to RL's importance as an element of SCM $[77,78]$ and to the increasing attention devoted to it, organizations have begun to shift from merely serving customers with a single (initial) transaction to serving customers' long-term needs, especially when products are returned, exchanged or superseded by a new product $[79,80]$.

This study tested the proposed research model using multiple and moderated regression analyses [74] to test the hypotheses by introducing the moderating effect as a multiplicative variable.Via this methodology, the study found, first, that the development of technological skills by workers involved in RL processes improved the accessibility of information and collaboration among people and processes, while also using these more efficiently to enable the organization to improve its competitive position [31].

Second, the greater the TMS for IT, the stronger the relationship between technological skills and RL; that is, TMS for IT strengthened the positive effect of technological skills on the development of RL processes. TMS for IT use significantly affected RL projects by enabling the construction of a solid infrastructure to generate greater commitment of the organization's employees to foster learning and develop technological abilities [81].

In addition, the greater the degree of innovativeness, the stronger the relationship was between technological skills and RL. Today's dynamic environments require firms to participate more extensively in sustainable management business activities, which strengthen companies' ability to face ongoing environmental change. Innovative strategies and SCM-based strategies of entrepreneurial culture are critical to such flexibility [82]. Fosteringemployees' technological skills requires having innovative environments that are flexible and creative and that permit the organization to improve its RL processes [35], thus strengthening its competitive advantage. Innovativeness can improve the impact of technological skills on RL processes, reducing costs and wait times in return processes, and 
thus, develop the flexibility to adjust to rapid changes in the business environment [83]. Creating and establishing entrepreneurial initiatives contributes to generating innovation, renewing the productive fabric and creating new jobs through the dissemination and exploitation of knowledge [84].

\subsection{Implications for Researchers}

Technology firms constitute a sector with high volatility and great change over time. Firms that compete in this sector must exploit new opportunities that enable them to develop activities to improve their competitive position [85]. Such firms can integrate RL activities into the supply chain to survive in the medium and long term. This study makes three main theoretical contributions.

First, thefindings showed the importance of employees' technological skills for RL activities in high-tech manufacturing firms.Second, theresults demonstrated the crucial role of TMS in IT, not only in providing tangible resources but also in supporting employees' professional development in RL. Managers' good management of employees' technological skills fosters good practices in RL processes (i.e., recycling and reuse of materials), which can support the supply chain in solving problems of incompatible data, environmental resistance from the customer and greater social consciousness in the RL chain [85]. Finally, the key influence of innovativeness on organizational flexibility and creativity [31] can strengthen the relationship between technological skills and RL.

\subsection{Implications for Managers}

Regarding the implications for business management, TMS can mean investment in RL based on new technologies that enable better coordination with customers in RL processes. Firms that seek to improve SCM, and particularly to perform RL processes, must invest more in IT infrastructure and exploit their employees' IT knowledge and skills. That is, in addition to possessing new technologies, the firm must know how to exploit its internal resource base and the potential of its labor capacity to create intangible value and differentiate itself from the competition [85].

Collaborating with customers to deliver RL increases customers' satisfaction and the firm's reputation and brand value. PerkinElmer (a technology firm related to health and the environment) used RL practices to foster sustainable development in its supply chain by encouraging customers through a $10 \%$ discount to return equipment to the firm once they no longer needed it. PerkinElmer implemented this strategy to reduce its environmental impact and that of its products, improve relationships with customer and lower processing cost (remanufacturing costs less than manufacturing new equipment) [85].

\subsection{Limitations and Future Research}

Among this study's limitations, the transversal character of the research advises caution in interpreting the results to behavior over time. As our data were collectedin 2010, it would be interesting to repeat the study and compare the results. Our theoretical framework took care, however, to attempt to determine formal cause-effect relationships. Future longitudinal studies would improve this study's accuracy.

Similarly, we attempted to mitigate common method bias. Podsakoff et al. (2003) [86] argued that two major measures can be taken to reduce the risk ofthis bias: (1) anonymity of the survey results, and (2) improvement of items used to measure constructs. We incorporated both recommendations. The study goals were stated clearly, and respondents were assured that the survey would remain anonymous. Furthermore, following the significant recommendations of Podsakoff et al. (2003) [86], we tested and validated scales carefully to ensure that the items were clearly worded and not ambiguous. Additionally, we developed our scales from previously tested scales.

In accordance with suggestions in the very recent and relevant literature (e.g., [23]), it would be of great interest for future studies to use a holistic model to analyze internal and external issues that condition the RL process. In this respect, first, it would be very useful to distinguish between technological and non-technological capabilities when defining the internal organizational factors 
that play a stronger role in conditioning RL processes. Second, we stress the importance of studying the influence of stakeholders on the performance of RL practices and processes. In fact, we should not forget that multiple agents outside the firm are involved in a firm's RL process. Finally, future studies could deepen understanding of the use of a contingent model that permits establishment of whether the antecedents that explain RL performance can be conditioned by such issues as the firm's innovation capacity, innovative culture, activity sector (especially sectors that require high investment in technology) and internationalization process.

Author Contributions: The authors contributed equally in designing and development of the paper. Furthermore, the corresponding author did lead the review response process and resubmission tasks to the journal.

Funding: This research was funded by Andalusian Regional Government [Research Project P11.SEJ.7988], the Ministry of Economy and Competence of Spain through Project [ECO2016-75909-P; ECO2017-88222], project of the University of Granada [PPJI2017-01], and the program of the Faculty of Economic and Business Sciences of the University of Granada for the revision of scientific texts.

Conflicts of Interest: The authors declare no conflict of interest.

\section{Appendix A}

- $\quad$ Top Management Support for IT.

Indicate the degree to which you agree or disagree with the following statements about top management support.

1. Top management cultivates technology project champions.

2. Top management ensures adequate funding of technology research and development.

3. Top management restructures work processes to leverage technology opportunities in the organization.

4. Top management facilitates technology transfer throughout the organization.

- Technological Skills.

Indicate the extent to which you agree or disagree with the following statements in relation to the units' technical skills. Answers may refer to a department or the person in charge of technology.

1. Unit skills in the object-oriented languages and systems for customer-server application development are excellent.

2. Item measures for IT department technical skills in business application software performance are very superior to those of the closest competitors.

3. Item measures for IT department technical skills in communication services efficiency are very superior to those of the closest competitors.

4. Information systems unit skills in fourth-generation programming languages areas are excellent.

- Organizational Innovativeness.

Where applicable, indicate the extent of changes that have taken place in your company over the past three years.

1. Your company's spending on new product/process development activities.

2. Number of new products/processes added and introduced by your company.

3. Your adoption of technologies developed by other companies or industries.

4. Top management emphasis on $R \& D$, technological leadership and innovation rather than marketing. 
- Reverse Logistics.

Please indicate your degree of agreement or disagreement with the following statements related to the characteristics of your company. Reverse logistics processes are important or might be important for my company because:

1. They involve cost reduction.

2. They improve service quality.

3. They result in better prices.

4. They improve the return policy (returned material).

5. They improve product variety.

6. They improvedelivery speed (time).

- Organizational Performance

Relative to your main competitors, what is your firm's performance in the last three years in the following areas?

1. Organizational performance measured by return on assets (economic profitability or ROA)

2. Organizational performance measured by return on equity (financial profitability or ROE)

3. Organizational performance measured by return on sales (percentage of profits over billing volume)

4. Recovery of investments

5. Organization's market share in its main products and markets

6. Growth of sales in its main products and markets

\section{References}

1. Wisner, J.D.; Tan, K.C.; Leong, G.K. Principles of Supply Chain Management: A Balanced Approach, 2nd ed.; South-Western, Cengage Learning: Mason, OH, USA, 2008.

2. Rogers, D.S.; Tibben-Lembke, R.S. Going Backwards: Reverse Logistics Trends and Practices; Reverse Logistics Executive Council: Pittsburgh, PA, USA, 1999.

3. Wernerfelt, B. A Resource-based view of the firm. Strateg. Manag. J. 1984, 5, 171-180. [CrossRef]

4. Hart, S.L. A natural-resource-based view of the firm. Acad. Manag. Rev. 1995, 20, 986-1014. [CrossRef]

5. Mihi Ramírez, A. Un Análisis Causal de la Relación Entre la Creación del Conocimiento y la Logística Inversa; Universidad de Granada: Granada, Spain, 2010; Available online: http://hdl.handle.net/10481/4935 (accessed on 10 December 2018).

6. Lee, C.K.M.; Lam, J.S.L. Managing reverse logistics to enhance sustainability of industrial marketing. Ind. Mark. Manag. 2012, 41, 589-598. [CrossRef]

7. Faisal, M.N. Sustainable Supply chains: A study of interaction among the enablers. Bus. Process Manag. J. 2010, 16, 508-529. [CrossRef]

8. Jayaraman, V.; Ross, A.; Agarwal, A. Role of information technology and collaboration in reverse logistics supply chain. Int. J. Logist. Res. Appl. 2008, 11, 409-425. [CrossRef]

9. Beske, P.; Seuring, S. Putting sustainability into supply chain management. Supply Chain Manag. Int. J. 2014, 19, 322-331. [CrossRef]

10. Dubey, R.; Gunasekaran, A.; Childe, S.J.; Wamba, S.F.; Papadopoulos, T. The impact of Big Data on world-class sustainable manufacturing. Int. J. Adv. Manuf. Technol. 2016, 84, 631-645. [CrossRef]

11. Ferreira, M.A.; Jabbour, C.J.C.; de Sousa Jabbour, A.B.L. Maturity levels of material cycles and waste management in a context of green supply chain management: An innovative framework and its application to Brazilian cases. J. Mater. Cycles Waste Manag. 2015, 19, 516-525. [CrossRef]

12. Luthra, S.; Garg, D.; Haleem, A. An analysis of interactions among critical success factors to implement green supply chain management towards sustainability: An Indian perspective. Resour. Policy 2015, 46, 37-50. [CrossRef] 
13. Walker, H.; Jones, N. Sustainable supply chain management across the UK private sector. Supply Chain Manag. Int. J. 2012, 1, 15-28. [CrossRef]

14. Hazen, B.T.; Cegielski, C.G.; Hanna, J.B. Diffusion of green supply chain management: Examining perceived quality of green reverse logistics. Int. J. Logist. Manag. 2011, 22, 373-389. [CrossRef]

15. Prakash, C.; Barua, M.K. Integration of AHP-TOPSIS method for prioritizing the solutions of reverse logistics adoption to overcome its barriers under fuzzy environment. J. Manuf. Syst. 2015, 37, 599-615. [CrossRef]

16. Ravi, V.; Shankar, R. Analysis of interactions among the barriers of reverse logistics. Technol. Forecast. Soc. Chang. 2005, 72, 1011-1029. [CrossRef]

17. Mai, E.; Chen, H.; Anselmi, K. The role of returns management orientation, internal collaboration and information support in reverse logistics. J. Transp. Manag. 2012, 23, 45-59.

18. Myerson, P.A. Supply Chain and Logistics Management Made Easy: Methods and Applications for Planning, Operations, Integration, Control and Improvement, and Network Design; FT Press: Upper Saddle River, NJ, USA, 2015.

19. Sharma, S.K.; Panda, B.N.; Mahapatra, S.S.; Sahu, S. Analysis of barriers for reverse logistics: An Indian perspective. Int. J. Model. Optim. 2011, 1, 101-106. [CrossRef]

20. Srivastava, S.K. Reverse Supply Chains: Issues and Analysis; CRC Press Inc.: Boca Raton, FL, USA, 2013.

21. Barney, J.B. Firm resources and sustained competitive advantage. J. Manag. 1991, 17, 99-120. [CrossRef]

22. Grant, R.M. Toward a knowledge based theory of the firm. Strateg. Manag. J. 1996, 17, 109-122. [CrossRef]

23. Ansari, Z.N.; Kant, R. A state-of-art literature review reflecting 15 years of focus on sustainable supply chain management. J. Clean. Prod. 2017, 142, 2524-2543. [CrossRef]

24. Daugherty, P.J.; Myers, M.B.; Richey, R.G. Information support for reverse logistics: The influence of relationship commitment. J. Bus. Logist. 2002, 23, 85-106. [CrossRef]

25. Daugherty, P.J.; Richey, R.G.; Genchev, S.E.; Chen, H. Reverse logistics: Superior performance through focused resource commitments to information technology. Transp. Res. Part E Logist. Transp. Rev. 2005, 41, 77-92. [CrossRef]

26. Christopher, M. Logistics and Supply Chain Management, 4th ed.; Henry Ling: Dorchester, UK, 2011.

27. Wade, M.; Hulland, J. The resource-based view and information systems research: Review, extension, and suggestions for future research. MIS Q. 2004, 28, 107-142. [CrossRef]

28. Benavides Velasco, C.A.; Quintana Garcia, C. Proceso y sistemas organizativos para la gestión del conocimiento: El papel de la calidad total. Bol. ICE Econ. 2005, 2838, 37-52.

29. Ho, G.T.S.; Choy, K.L.; Lam, C.H.Y.; Wong, D.W.C. Factors affecting implementation of reverse logistics: A survey among Hong Kong businesses. Meas. Bus. Excell. 2012, 16, 29-46. [CrossRef]

30. Richey, R.G.; Genchev, S.E.; Daugherty, P.J. The role of resource commitment and innovation in reverse logistics performance. Int. J. Phys. Distrib. Logist. Manag. 2005, 35, 233-257. [CrossRef]

31. Huscroft, J.R.; Hazen, B.T.; Hall, D.J.; Skipper, J.B.; Hanna, J.B. Reverse logistics: Past research, current management issues, and future directions. Int. J. Logist. Manag. 2013, 24, 304-327. [CrossRef]

32. McCracken, M.; Wallace, M. Towards a redefinition of strategic HRD. J. Eur. Ind. Train. 2000, 24, $281-290$. [CrossRef]

33. Christmann, P. Effects of "best practices" of environmental management on cost advantage: The role of complementary assets. Acad. Manag. J. 2000, 43, 663-680.

34. Huang, Y.C.; Yang, M.L. Reverse logistics innovation, institutional pressures and performance. Manag. Res. Rev. 2014, 37, 615-641. [CrossRef]

35. Martin-de Castro, G.; Delgado-Verde, M.; Navas-López, J.E.; Cruz-González, J. The moderating role of innovation culture in the relationship between knowledge assets and product innovation. Technol. Forecast. Soc. Chang. 2013, 80, 351-363. [CrossRef]

36. Sarkis, J.; Helms, M.M.; Hervani, A.A. Reverse Logistics and Social Sustainability. Corp. Soc. Responsib. Environ. Manag. 2010, 17, 337-354. [CrossRef]

37. Mata, F.J.; Fuerst, W.L.; Barney, J.B. Information technology and sustained competitive advantage: A resource based analysis. MIS Q. 1995, 19, 487-505. [CrossRef]

38. García-Sánchez, E.; García-Morales, V.J.; Bolívar-Ramos, M.T. The influence of top management support for ICTs on organisational performance through knowledge acquisition, transfer, and utilisation. Rev. Manag. Sci. 2017, 11, 19-51. [CrossRef] 
39. Morgan, T.R.; Glenn Richey, R., Jr.; Autry, H.W. Developing a reverse logistics competency: The influence of collaboration and information technology. Int. J. Phys. Distrib. Logist. Manag. 2016, 46, 293-315. [CrossRef]

40. Civi, E. Knowledge management as a competitive asset: A review. Mark. Intel. Plan. 2000, 18, $166-174$. [CrossRef]

41. Anderson, J.C.; Narus, J.A. A model of the distributor's perspective of distributor-manufacturer working relationship. J. Mark. 1984, 48, 62-74. [CrossRef]

42. Aitken, J.; Harrison, A. Supply governance structures for reverse logistics systems. Int. J. Oper. Prod. Manag. 2013, 33, 745-764. [CrossRef]

43. Gu, Q.; Jiang, W.; Wang, G.G. Effects of external and internal sources on innovation performance in Chinese high-tech SMEs: A resource-based perspective. J. Eng. Technol. Manag. 2016, 40, 76-86. [CrossRef]

44. Bowersox, D.J.; Close, D.J.; Stank, T.P. How to master cross-enterprise collaboration. Supply Chain Manag. Rev. 2003, 7, 18-27.

45. Lewis, I.; Talalayevsky, A. Logistics and information technology: A coordination perspective. J. Bus. Logist. 1997, 18, 141-157.

46. Rajeswari, K.S.; Anantharaman, R.N. Development of a scale to measure stress among software professionals: A factor analytic study. In Proceedings of the ACM SIGCPR Conference, Philadelphia, PA, USA, 10-12 April 2003; pp. 34-43.

47. Agrawal, S.; Singh, R.K.; Murtaza, Q. A literature review and perspectives in reverse logistics. Resour. Conserv. Recycl. 2015, 97, 76-92. [CrossRef]

48. Wittstruck, D.; Teuteberg, F. Understanding the success factors of sustainable supply chain management: Empirical evidence from the electrics and electronics industry. Corp. Soc. Responsib. Environ. Manag. 2012, 19, 141-158. [CrossRef]

49. Grant, R.M. The Resource-Based Theory of Competitive Advantage: Implications for Strategy Formulation. Calif. Manag. Rev. 1991, 33, 114-135. [CrossRef]

50. Tsai, W.C.; Tang, L.L. A model of the adoption of radio frequency identification technology: The case of logistics service firms. J. Eng. Technol. Manag. 2012, 29, 131-151. [CrossRef]

51. Ngai, E.W.T.; Chau, D.C.K.; Poon, J.K.L.; Chan, A.Y.M.; Chan, B.C.M.; Wu, W.W.S. Implementing an RFID-based manufacturing process management system: Lessons learned and success factors. J. Eng. Technol. Manag. 2012, 29, 112-130. [CrossRef]

52. Porter, M.E. The five competitive forces that shape strategy. Special Issue on HBS Centennial. Harv. Bus. Rev. 2008, 86, 78-93.

53. Byrd, A.; Davidson, N. Examining possible antecedents of IT impact on the supply chain and its effect on firm performance. Inf. Manag. 2003, 41, 243-255. [CrossRef]

54. Ravichandran, T.; Liu, Y. Environmental determinism and strategic choice: Exploring the determinants of information technology investment strategy. Decis. Sci. 2011, 42, 537-574. [CrossRef]

55. Lee, J.; Park, S.; Baker, R. The moderating role of top management support on employees' attitudes in response to human resource development efforts. J. Manag. Organ. 2018, 24, 369-387. [CrossRef]

56. Rogers, E. Diffusion of Innovations, 5th ed.; Free Press: New York, NY, USA, 2003.

57. Pesämaa, O. Personnel and action control in gazelle companies in Sweden. J. Manag. Control 2017, 28, 107-132. [CrossRef]

58. Frohman, A. Building a culture for innovation. Res. Technol. Manag. 1998, 41, 9-12. [CrossRef]

59. Pérez, D.; Dressler, M. Tecnologías de la información para la gestión del conocimiento. Intang. Cap. 2007, 15, 31-59.

60. Amadeus. 2009. Available online: http://amadeus.bvdep.com/ip/ (accessed on 6 April 2010).

61. Baer, M.; Frese, M. Innovation is not enough: Climate for initiative and psychological safety, process innovations, and firm performance. J. Organ. Behav. 2003, 24, 45-68. [CrossRef]

62. Westphal, J.D.; Fredickson, J.W. Who directs strategic change? Director experience, the selection of new CEOs, and change in corporate strategy. Strateg. Manag. J. 2001, 22, 1113-1137. [CrossRef]

63. Mihi-Ramirez, A. Product return and logistics knowledge: Influence on performance of the firm. Transp. Res. Part E Logist. Transp. Rev. 2012, 48, 1137-1151. [CrossRef]

64. Armstrong, J.S.; Overton, T.S. Estimating nonresponse bias in mail surveys. J. Mark. Res. 1977, 14, $396-403$. [CrossRef] 
65. Konrad, A.M.; Linnehan, F. Formalized HRM structures: Coordinating equal employment opportunity or concealing organizational practice? Acad. Manag. J. 1995, 38, 787-820. [CrossRef]

66. Podsakoff, P.M.; Organ, D.W. Self-reports in organization research: Problems and prospects. J. Manag. 1986, 12, 531-544.

67. Ray, G.; Muhanna, W.A.; Barney, J.B. Information technology and the performance of the customer service process: A resource-based analysis. MIS Q. 2005, 29, 625-652. [CrossRef]

68. Zahra, S.A. Environment, corporate entrepreneurship, and financial performance: A taxonomic approach. J. Bus. Ventur. 1993, 8, 319-340. [CrossRef]

69. Murray, J.; Kotabe, M. Sourcing strategies of U.S. service companies: A modified transaction-cost analysis. Strateg. Manag. J. 1999, 20, 791-809. [CrossRef]

70. Choi, J.; Kim, B.; Liu, X.; Simunic, D. Audit pricing, legal liability regimes, and Big 4 premiums: Theory and cross-country evidence. Contemp. Account. Res. 2008, 25, 1-49. [CrossRef]

71. Douglas, T.J.; Judge, W.Q. Total quality management implementation and competitive advantage: The role of structural control and exploration. Acad. Manag. J. 2001, 44, 158-169.

72. Homburg, C.; Workman, J.P., Jr.; Krohmer, H. Marketing's influence within the firm. J. Mark. 1999, 63, 1-17. [CrossRef]

73. Venkatraman, N.; Ramanujam, V. Measurement of business performance in strategy research: A comparison of approaches. Acad. Manag. Rev. 1986, 11, 801-814. [CrossRef]

74. Cohen, J.; Cohen, P. Applied Multiple Regression/Correlation Analysis for the Behavioural Sciences, 2nd ed.; Laurence Erlbaum: Hillsdale, NJ, USA, 1983.

75. Venkatraman, N. Strategic orientation of business enterprises: The construct, dimensionality and measurement. Manag. Sci. 1989, 35, 942-962. [CrossRef]

76. Hair, J.F.; Black, W.C.; Babin, B.J.; Anderson, R.E. Multivariate Data Analysis; Prentice Hall: Upper Saddle River, NJ, USA, 2009.

77. Lambert, D.M. An Executive Summary of Supply Chain Management: Process, Partnerships, Performance; The Hartley Press, Inc.: Jacksonville, FL, USA, 2008.

78. Rogers, P.; de Silva, R.; Bhatia, R. Water is an economic good: How to use prices to promote equity, efficiency and sustainability. Water Policy 2002, 4, 1-17. [CrossRef]

79. Mason, S. Backward progress. IIE Solut. 2002, 34, 42-46.

80. Tibben-Lembke, R. Life after death: Reverse logistics and the product life cycle. Int. J. Phys. Distrib. Logist. Manag. 2002, 32, 223-244. [CrossRef]

81. Liang, H.; Saraf, N.; Hu, Q.; Xue, Y. Assimilation of enterprise systems: The effect of institutional pressures and the mediating role of top management. MIS Q. 2007, 31, 59-87. [CrossRef]

82. Sharma, S. Managerial interpretations and organizational context as predictors of corporate choice of environmental strategy. Acad. Manag. J. 2000, 43, 681-697.

83. Stundza, T. Supply Chain Innovation Is Important, Purchasing. 2009. Available online: http://www. purchasing.com/article/354518Supply_chain_innovation_is_important.php (accessed on 10 December 2018).

84. Acs, Z.; Plummer, L. Penetrating the knowledge filter in regional economies. Ann. Reg. Sci. 2005, 39, 439-456. [CrossRef]

85. Ajamieh, A.; Benitez, J.; Braojos, J.; Gelhard, C. IT infrastructure and competitive aggressiveness in explaining and predicting performance. J. Bus. Res. 2016, 69, 4667-4674. [CrossRef]

86. Podsakoff, P.M.; MacKenzie, S.B.; Lee, J.Y.; Podsakoff, N.P. Common method biases in behavioral research: A critical review of the literature and recommended remedies. J. Appl. Psychol. 2003, 88, 879-903. [CrossRef] [PubMed]

(C) 2018 by the authors. Licensee MDPI, Basel, Switzerland. This article is an open access article distributed under the terms and conditions of the Creative Commons Attribution (CC BY) license (http:/ / creativecommons.org/licenses/by/4.0/). 